\title{
12
}

\section{Public accountability: Conceptual, historical and epistemic mappings}

\author{
Michael W Dowdle
}

\section{Introduction: On the crisis in public accountability}

Many in the Anglo-American world perceive a growing crisis in public accountability. They fear that privatisation and globalisation are breaking down the traditional accountability arrangements that give us confidence in our government-for example, by devolving important political authority and power to private actors who are able to operate outside the public accountability mechanisms designed for civil servants, or by shifting governmental powers and responsibilities on to transnational actors, both public and private, who operate outside the jurisdictional reach of domestically formulated accountability systems (see Drahos, Chapter 15; Tusikov, Chapter 20, this volume). All this leads to suspicion about whether the political forces affecting our lives are really acting in the interest of the public.

1 Adapted from Dowdle, M 2006. 'Public accountability: Conceptual, historical, and epistemic mappings', in MW Dowdle (ed.), Public Accountability: Designs, Dilemmas and Experiences. Cambridge: Cambridge University Press, pp. 1-32. 
This crisis is further exacerbated by the fact that different people seem to have different and often conflicting ideas as to what constitutes or satisfies a meaningfully 'public' accountability. Economic development agencies, for example, tend to see public accountability primarily in terms of rationalised and transparent systems of bureaucratic control. Human rights activists see it primarily in terms of popular participation in and supervision of political decision-making. Legal development agencies often see it in terms of judicial enforcement of legal norms. Many regulatory reformers in the United States and the United Kingdom see it in terms of market-like competition and discipline. Thus, while there is common perception of an accountability problem, there is also deep division about its exact causes and nature and about what our appropriate response to that problem should be.

As will be explored in this chapter, this is because different visions of public accountability reflect different histories, different experiences and different concerns. Historically, these differences have been harmonised somewhat by the conceptual predominance of what we will call the bureaucratic mode of public accountability. Recent events, however, have weakened this predominance and, in so doing, have catalysed inconsistencies between and among these various ways of experiencing public accountability.

Part 2 of this chapter looks at the historical roots of present-day AngloAmerican understandings of public accountability. As we will see, that understanding is very much the product of historical accretion, embedding within it different ways that generations past perceived and responded to accountability crises. As we will see in Part 3, what stabilised this accretional collection of historical experiences and responses until recently was the relative conceptual dominance of one particular kind of public accountability: bureaucratic accountability. Part 4 will explore how recent evolutions in global and domestic governance have reduced the appeal of bureaucratic accountability and, in the process, catalysed conceptual inconsistencies with and among these other conceptualisations, resulting in a growing fragmentation of our present-day notions of public accountability-the 'crisis' referred to in the opening of this chapter.

In Part 5, we will see that underlying this fragmentation is the fact that we as individuals actually experience accountability in a number of different ways: as subjects of state power; as evaluators of state institutions; as citizen participants in the state itself (as popular 
sovereigns, in other words); and simply as human beings interacting with other human beings. Each of these ways of experiencing public accountability has its own distinct logic and its own distinct epistemology. This suggests that the key for a more robust understanding of the nature of public accountability lies in a consilience involving these different kinds of experience, as will be explored in Part 6. Finally, Part 7 concludes by exploring what all this might have to tell us about where the 'responsiveness' in 'responsive regulation' really lies.

\section{An intellectual history of public accountability}

In beginning our exploration of the diverse structural and experiential facets of the notion of public accountability, we might first ask ourselves what is public accountability? At its heart, the idea of public accountability seems to express a belief that people with public responsibilities should be answerable to 'the people' for the performance of their duties (see also Mashaw 2006). But there are problems with this conceptualisation.

This standard conceptualisation of public accountability is really simply a metaphor that borrows very imperfectly from a number of other discourses about 'accountability' per se. From the private law, it borrows from the notion that accountability is a product of a particular kind of relationship existing between two individuals-namely, the principal and her agent, in which the agent is required to demonstrate that her actions conform to the demands, intentions and interests of the principal. It then borrows from political theory the idea that the 'public' itself can be analogised to an individual (in this case, the individual of principal in private law). The problem is, of course, that the 'public' is not an individual. As an inherently collective phenomenon, the 'public' is only vaguely identifiable in space. Its corpus is diffuse and contestable, and its internal dynamics are often so complex as to be opaque. As a collective, it rarely can be said to have mental-state intentions, as what 'intentions' it might be meaningfully said to have are often internally inconsistent (see Loughlin 2010).

Perhaps because of this conceptual conundrum, Anglo-American political and legal society has tended to define public accountability primarily in terms of discrete institutional architectures. Most prominent among these have been elections, rationalised bureaucracies, judicial review, 
transparency and 'markets'. These different architectural modalities originally emerged as contingent responses to various legitimacy crises that have periodically beset Anglo-American governance. In other words, as implemented in the Anglo-American legal system, public accountability is more a spontaneous aggregation of experiences than a structural extrapolation of foundational principles.

Elections have been a key component of Anglo-American conceptions of public accountability ever since the founding of the American constitution. In the United States, electoral recall originally represented the principal sanction by which the citizenry was to hold politicians accountable for errant political frolics (Keyssar 2000; see also Madison 1961).

But even in the Anglo-American world, intellectual and political support for electoral democracy has always been decidedly mixed. In the United States at the end of the nineteenth century, the ability of machine-style, patronage-based politics to thrive in democratic competition, at the seeming expense of the public good, caused many to become sceptical of the electorate's capacity to hold politics to true public account. Reformers sought, instead, to hold political behaviour to such account via the construction of rationalised, professionalised bureaucratic frameworks. To these reformers, devices such as meritocratic recruitment, tenure and promotion; professionalisation; and scientific administration offered a more satisfying vision of public accountability. It was a vision of public accountability that worked by subjecting political behaviour to the oversight of an organisational environment specifically designed to recognise and pursue the public good as opposed to that relying primarily on corruptible electoral impulses (Lee 2011).

But, about the same time as Americans were turning to bureaucracy as a cure for perceived accountability problems of electoral democracy, constitutional scholars in England began turning to the judiciary as a cure for the perceived accountability problems of both democracy and bureaucracy. In the 1880s, the influential English constitutional law scholar Albert Venn Dicey became concerned-some might even say obsessed (see,for example,Schneiderman 1977) — with both the expanded administrative capacities of the British state and the expansion of the franchise. Dicey (1982) advanced an idea-what he famously called 'rule of law' - that the only way to secure constitutional constraints in the face of these twin expansions was to preserve and strengthen the politicallegal oversight of bureaucratically and democratically insulated courts. 
In the 1930s, American jurists also became increasingly concerned about perceived constitutional threats brought about by the emergence of the American administrative state, and they were strongly influenced by Dicey's description of the need for a strong judicial check on the growing administrative bureaucracy (Horowitz 1992: 225-8). But Dicey's vision saw judicial review primarily as a substantive constraint of bureaucratic decision-making. The American vision, in contrast, adopted a more process-focused approach (White 1978: 136-63).

In the 1960s and 1970s, rising disillusionment in government generated first by American participation in the Vietnam War and later by the Watergate scandal caused many to become sceptical about the degree to which either professionalised rationalisation or judicial review could encourage public officials to work in the public interest. This occasioned the appearance of a yet another architectural modality for political accountability - that of 'transparency' and 'open government' (Anechiarico and Jacobs 1996: 8, 23-6). Open government sought to make governmental decision-making as visible as possible-not simply to those who directly involve themselves with government, but also to the larger, uninvolved portion of the polity. This new vision of open government promised to allow our increasingly remote civil society to nevertheless hold public officials to account even without directly participating in political decision-making.

But soon thereafter, in the 1970s, economic stagnation in the United States and the United Kingdom caused growing concern about governmental waste, inefficiency and unresponsiveness. This caused some reformers to look to market-like mechanisms-which they believed to be more efficient in the allocation and usage of resources-as a means of promoting responsible use of public resources. In some cases, these reformers advocated devolving public responsibilities directly to private, market-based actors (Savas and Schubert 1987). Beyond this, reformers in the United Kingdom also invented new governance architectures that replicated market-like forces of competition by having different public departments 'compete' in the development of effective regulation (Hood 1995), while American reformers developed architectures and procedures, such as cost-benefit analyses, that sought to replicate marketlike pricing and demand mechanisms (Layard and Glaister 1994). 


\section{Stability and contiguity}

In sum, the Anglo-American idea of public accountability is not so much the product of extrapolation from core conceptual principles as an accretional layering of responses to periodic legitimacy exigencies experienced by Anglo-American societies. But why and how did these successive modalities aggregate into a singular conception of public accountability, rather than simply producing a sequence of competing conceptual paradigms?

For most of the twentieth century, the stability of this accretional layering has been due largely to the fact that one particular modality of public accountability - bureaucracy - has enjoyed a privileged, primus inter pares status when it came into conflict with other modalities (Rubin 2006). Of course, this predominance was not always the case. We noted above that elections were the principal recognised source of public accountability for the first 100 years of American constitutional government. When American reformers began promoting bureaucratisation as an accountability alternative to democracy, however, they triggered a corresponding reconceptualisation of the nature of democracy itself. 'Democracy' came to be thought of in the more limited terms of elections and suffrage, as opposed to the more robust notion of 'participation' famously described by Tocqueville (1969) in 1835. Reorienting the idea of democracy in this way avoided conflict with growing norms of bureaucratisation and professionalisation, both of which sought to remove the more day-to-day, technocratic matters of public administration from the partisan politics that a more participatory vision of democracy seemed to unleash (Keyssar 2000: 117-71).

A similar clearing of space occurred when the expanded capacities of bureaucratised administrative government also brought it into conflict with judicial review. As described above, constitutional scholars in both the United Kingdom and the United States had originally hoped that pre-existing processes of judicial review could be used to put a brake on the inherent dangers of bureaucratic administrative governance; however, this was not to be the case. Both UK and US courts have adopted a vision of judicial review that was largely deferential to the substance of bureaucratic decision-making. During the first two-thirds of the twentieth century, the UK courts' deference to the administrative state has been so complete that there was a real question whether judicial review in the United Kingdom had any real meaningful impact on the 
actual operations of administrative governance (JUSTICE-All Souls Review Committee 1988). On the other side of the Atlantic, the US courts have also decided-wisely, in the eyes of many-to generally defer to bureaucratic judgement, at least when it follows proper processes (Kagan 2001: 2383).

Nor have the more recent modalities of public accountability-for example, open government, deregulation, privatisation and contracting out-seriously challenged bureaucratisation's dominance as our main paradigm for public control. The 'open government' movement of the late 1960s and early 1970s quickly subordinated itself to the perceived needs of bureaucratic government. For example, the Freedom of Information Act is qualified by its famous Exemption 5, which allows an agency to lawfully withhold 'inter-agency or intra-agency memorandums or letters which would not be available by law to a party other than an agency in litigation with the agency' (5 U.S.C. $§ 552(b)(5))$. The exemption was thought necessary, in the words of the US Supreme Court, to protect the innately bureaucratic 'decision making processes of government agencies' (NLRB v. Sears, Roebuck \& Co. 421 U.S. 132 (1975) 150).

More recent, market-inspired governmental reforms such as contracting out, devolution and 'streamlined government'-despite often being motivated by expressly antibureaucratic impulses-have, for the most part, simply substituted one (often less visible) bureaucracy for another. In the United States, for example, an overall decrease in the size of the federal bureaucracy during the 1990s has been offset by corresponding increases in the size of state government bureaucracies (Diiulio, jr, and Kettl 1995). Decreases in public bureaucratic responsibilities due to 'contracting out' have been counterbalanced by increased private bureaucratic responsibilities within contracting firms (Light 1999: 4). Thus, despite their often expressly antibureaucratic intentions, this most recent round of regulatory reforms has not so much challenged bureaucratic accountability as it has shifted it around.

\section{Fragmentation}

More recent events, however, have disrupted the stability of this 'accretional' vision of public accountability. We noted above that this vision has been sustained in part by the pride of place it gives to bureaucratic structuring. One of the reasons bureaucratisation has 
been able to enjoy this position is because it was most consistent with the evolving organisational trends of what we might call 'modernised' Anglo-American society as it emerged in the early twentieth century (Piore and Sabel 1984: 49-104). Industrialisation occasioned a massive rationalisation, regularisation and centralisation of social life. The rationalisation, regularisation and centralisation that characterise bureaucratic administration worked in significant part by paralleling this development (see also Dowdle 2006). However, recent developments have caused both domestic and international regulatory environments to become increasingly volatile and fragmented. As a result, regulatory systems are being reoriented to emphasise flexibility and adaptability, at the expense of bureaucratic predictability and control (Sabel 1994).

Another reason for the disruption of the Anglo-American vision of public accountability has to do with recent developments in the global environment. During the last half of the twentieth century, what we are calling the Anglo-American 'model' of public accountability also became increasingly transnationalised, due in significant part to the United States's dominant position within the global geopolitical arena (see, for example, Mazower 1999: 294-6; cf. Erkkilä 2007). This transnational tolerance of America's intellectual dominance with regards to issues of public accountability had been sustained in part by the First World's perceived need to present a united front against communism in general and the Soviet Union in particular. With the collapse of the Soviet Union, however, this united, US-led vision of what constituted good, or even democratic, governance has come under increased scrutiny. At the same time, new technologies have enabled formerly isolated, localised activists to join international networks of like-minded resistors and activists. A growing number of self-consciously 'local' interests are now increasingly able to contest, both normatively and practically, their assimilation into centralising, bureaucratic regulatory frameworks (see, for example, Morgan 2006). For both these reasons, the AngloAmerican vision of public accountability, which used to be seen as a bulwark for liberal political stability, is now seen by many as an instrument of political hegemony (Jayasuriya 2001).

The result has been a 'fragmentation' in public accountability discourse. As the harmonising dominance of bureaucratic modernisation is delegitimised by newer and more localised organisational logics that stress flexibility and local knowledge, formerly latent tensions among the diverse architectural modalities that make up the Anglo-American 
vision of public accountability become more manifest. Different kinds of political interests tend to be attracted to different modalities of accountability. Trade unions, for example, whose impact on political decision-making historically has come in large part from their ability to mobilise voters, tend to prefer electoral modalities of accountability. International human rights organisations, whose staffs generally include a high number of people with legal training, tend to prefer juridical modalities of public accountability. Economically oriented interests seem to be more comfortable with what Weber (1947: 328-39) called the 'legal-rational model' of public authority, which meshes with their own institutional practices and makes it easier for them to navigate the diversity of transnational and domestic regulatory environments in which they must operate.

At the same time, globalisation has generated growing demands for more public accountability. The more willing participants in globalisation processes-for example, international business, trading interests, labour activists and environmental activists-are demanding an evermore expansive scope of public accountability from domestic government actors, whom they suspect to be illegitimately impeding the implementation of emerging public international norms (see, for example, Rodrik 1999: 151; Human Rights Watch 1999; AFL-CIO 2001: 47, 60). At the same time, more reluctant, involuntary and localised participants in the globalisation process demand increasing public accountability from transnational regulatory actors, whom they see as illegitimately interfering with what should be ultimately domestic political matters (see Tusikov, Chapter 20; and Tienhaara, Chapter 38, this volume).

\section{Experiences and epistemologies}

Compounding this fragmentation of the ideal of public accountability is the fact that we as individuals encounter public accountability in a variety of ways, due to the fact that our individual experience with public accountability is inherently fragmented (Pinker 2002: 220-1). For example, one way in which we encounter public accountability is as 'subjects' of the state's dominium and authority. Here, our experience with public accountability is passive and positivist. We are concerned 
primarily with what the existing demands of public accountability mean to us, as beneficiaries of others' conformity to these demands and/or as subjects who must conform to its demands.

Alternatively, we encounter public accountability as critical conceptualisers of political institutions - what we might refer to as an 'architectural' perspective. Of course, few of us ever have the opportunity to actually set up a public accountability system, but that does not stop us from thinking about how such a system should be designed or how it should work. Thus, when we think about the viability of electoral term limits or the problems of judicial activism, political lobbying or campaign finance, we generally think about these issues from a largely architectural perspective. We are not so much concerned about the subjective implications of these mechanisms-that is, how they affect us personally. Rather, we wonder more abstractly and objectively about what sort of implications these devices might have on mechanisms and dynamics of government.

We also encounter public accountability as citizens or as participants in the state. Here, 'accountability' itself is an inherently participatory experience. To give an account is to communicate, it is not to completely surrender control. Accountability is therefore a discursive condition, something that sets up a dialogue between the public and public servants. As members of the public, we actuate public accountability by deciding for ourselves whether the accounts offered by public officials are proper and in our interest, and how exactly we should respond in our actions to the officials offering these accounts.

Finally, we also encounter public accountability through direct experience (see, generally, Braithwaite 2006b). Consider, for example, our experience of being treated with respect and kindness. Such experience implicates a particular form of public accountability: it indicates to us that some other person is taking our own concerns into account. Another example would be when we experience ourselves behaving responsibly and accountably. Even as wholly private citizens, we still recognise that in certain aspects we, too, are and should be held accountable to a larger public (Gardner 2006). Our experiences with regards to both these examples rarely depend on our contemplated appreciations of the dynamics of political coercion or how our actions implicate institutional design. They are feelings that operate prior to our rational understandings of larger political contexts, and hence represent an encounter with public accountability that is distinct from the other kinds of encounters described above. 
Moreover, each of these different ways of encountering public accountability has its own, distinct logic. As 'subjects' of state dominium, we see public accountability primarily in terms of formal and positivist powers, authority and duties on the one hand; and rights, privileges and capacities on the other. These are the constructs that 'the state' uses to portray and define the scope of its coercive might (see, for example, Hohfeld 2001), and we therefore find these constructs useful in helping us negotiate our way along the state's institutional pathways.

When we look at the institutional architecture of public accountability, we use another kind of epistemic logic. Here, our concern is primarily with understanding institutional possibilities for promoting accountability, rather than simply with the demands of its positivist legalism (Foley 1990). Here, our epistemology is one that resembles scientific positivism, rather than the legal positivism of the above described state-subject perspective.

When we encounter public accountability as citizens-that is, as participants in, rather than simple subjects of, the state-we perceive our environment in more discursive terms. The epistemology of this perspective is dialogic (Habermas 1989; cf. Bakhtin 1986). This perspective sees accountability in terms of cooperation and agreement. The knowledge that governs this realm is more intimate, more nuanced and less conducive to positivist or scientific structuring. It is, in significant part, conventionalist and political-embedded in the stories and symbologies that we are forever sharing with other participants (Dunn 2000; Berger and Luckman 1966: 92-103).

Finally, the epistemic logic of what we are calling the experience of public accountability is primarily perceptual and phenomenological. It is largely pre-theoretical, founded in the irreducible complexities of tacit or practical knowledge. Like the dialogic logic of participation, the logic of experience has an emotive quality, often appearing in the form of intuition and gut feeling. But, unlike that dialogic logic, the logic of this realm can be personal and private. It need not depend on conventionalist confirmation (see Polanyi 1958).

The importance of recognising the fragmented nature of our experience with public accountability lies not in the possibility that it will help us resolve our disagreements about what accountability demands. Indeed, just the opposite. The fragmented nature of our own experience with public accountability would seem to mean that, at the end of the day, 
the hunt for a single, grand unified theory of public accountability is likely to be futile. The simple fact that we all individually have experience of a diversity of kinds of encounters with public accountabilityeach encounter governed by a distinct logic-suggests that at some fundamental level, these differences are not completely reducible to a single common experiential referent.

But, paradoxically, the inherently fragmented, accretional nature of our vision of public accountability could actually be a source of strength, rather than a weakness. While a unified theory of public accountability might provide some degree of Kantian psychic comfort, it would not and could not reflect the full diversity of our actual experience. No matter how it was structured, a unified theory would invariably delegitimise some experiences that contribute to our thriving. We need to embrace our multiplicity of epistemically conflicting approaches to public accountability if we are to make sense of that phenomenon.

\section{Consilience}

Although distinct, our differing realms of experience and knowledge are not insular. In fact, they are highly interdependent. New experiences and understandings in one realm can often be translated into new and useful understandings in another-a process Edward O. Wilson (1998) famously termed 'consilience'. Consilience refers to the generation of new, robust understandings of the human condition that occurs when different experiences and epistemologies come in contact with and learn from one another (on regulatory pluralism and local epistemologies, see Forsyth, Chapter 14, this volume). The fragmented and accretional nature of our vision of public accountability can work to help catalyse this kind of dynamic: by simultaneously legitimating a wide diversity of not entirely harmonious experiences, such fragmentation ultimately facilitates an especially inclusive discourse about the experience of public accountability. Our task, in this regard, should not be one of finding ways to dissolve this epistemic diversity, but one of finding ways to harness it - to use it to catalyse these new, more robust understandings of the human condition (cf. Looney 2004). 
Take bureaucratic accountability as an example. We saw, initially, that underlying the accountability crisis is a widespread dissatisfaction with a possible overreliance by modern governments on bureaucratic accountability. This dissatisfaction would seem to stem primarily from our experiences as subjects of state power, since it is as subjects of state power that we feel the coercive oppression of bureaucracy most directly and keenly (Rubin 2006). A more architectural perspective, however, suggests that the dichotomy between bureaucracy and other forms of accountability need not be as hard and fast as is commonly portrayedthat the state-subject's perception of bureaucracy can be dissolved somewhat by a more microanalytical approach to organisational design (see, for example, Braithwaite 2006a).

A citizen-participant's perspective, on the other hand, suggested that there were critical aspects of bureaucratic accountability that are likely to escape detection by design-based perspectives-aspects that lie in the irreducible complexities of social interaction (see Scott 2006). Some effective responses to the state-subject's dissatisfaction can therefore be found in collective learning from these experiences (see, for example, Courville 2006). But, to be useful, this new learning often has to be folded back into existing understandings and expectations. Therefore, our collective capacity to learn —or to learn effectively—is itself vitally informed by existing broad conceptual mappings that are captured primarily in what we have called the subject-oriented perspective (see, for example, Dorf 2006; cf. Dowdle 2006).

In other words, no single perspective captures the full dimension of public accountability. Effective understanding of, and responses to, the 'crisis' in public accountability must be epistemically collaborative. As noted above, our crisis in accountability is in some sense perpetual. Our disagreements about accountability are therefore also in some sense perpetual. Perhaps paradoxically, our best hope for the future may lie precisely in the fact that this perpetual disagreement provides an endless supply of raw material with which we can continually triangulate new and more robust understandings of the nature of public accountability. 


\section{Conclusion: From 'consilience' to 'responsive regulation'}

The dynamic described above-what I have been calling 'consilience'has special resonance with John Braithwaite's notion of 'responsive regulation'. Consider, along these lines, Braithwaite's 'responsiveregulatory' critique of Gunther Teubner's and Niklas Luhmann's notions of law as a normatively autonomous epistemic system:

In this regard my conception of responsiveness differs from Teubner's (1986) reflexiveness and Niklas Luhmann's autopoiesis. I do not see law and business systems as normatively closed and cognitively open. In a society with a complex division of labor the most fundamental reason as to why social systems are not normatively closed is that people occupy multiple roles in multiple systems. A company director is also a mother, a local alderman, and a God-fearing woman. When she leaves the board meeting before a crucial vote to pick up her infant, her business behavior enacts normative commitments from the social system of the family; when she votes on the board in a way calculated to prevent defeat at the next Council election, she enacts in the business normative commitments to the political system; when she votes against a takeover of a casino because of her religious convictions, she enacts the normative commitments of her church ... So much of the small and large stuff of organizational life makes a sociological nonsense of the notion that systems are normatively closed. Nor is it normatively desirable that they be normatively closed ... there is virtue in the justice of the people and of their business organizations bubbling up into the justice of the law, and the justice of the law percolating down into the justice of the people and their commerce. (Braithwaite 2006b: 885)

In this light, responsive regulation can be seen as the regulatory face of consilience. But recognising the distinctive cognitive processes of consilience also helps give us a deeper understanding of the dynamics that must underlie responsive regulation. As described above, consilience requires us to see the other side in its own light—not as an existential competitor but as a repository of some distinct, highly impacted 'local' knowledge. This suggests that to be truly responsive, responsive regulation must be able to see the world from the perspective of its subjects and, in particular, from the perspective of those subjects who resist its imperium. For it is there that the seeds of true responsiveness are to be found. 


\section{Further reading}

Ala'i, P and Vaughn, RG (eds) 2014. Research Handbook on Transparency. Cheltenham, UK: Edward Elgar.

Bovens, M, Goodin, RE and Schillemans T (eds) 2014. The Oxford Handbook of Public Accountability. Oxford: Oxford Univrsity Press.

Murphy, DD 2006. The Structure of Regulatory Competition: Corporations and Public Policies in a Global Economy. Oxford: Oxford University Press. doi.org/10.1093/acprof:oso/9780199216512.001.0001.

Powers, M 1999. The Audit Society: Rituals of Verification. Oxford: Oxford University Press. doi.org/10.1093/ acprof:oso/9780198296034.001.0001.

Przeworski, A, Stokes, SC and Manin, B (eds) 1999. Democracy, Accountability, and Representation. Cambridge: Cambridge University Press.

Silberman, BS 1993. Cages of Reason: The Rise of the Rational State in France, Japan, the United States and Great Britain. Chicago: University of Chicago Press.

Skowronek, S 1982. Building a New American State: The Expansion of National Administrative Capacities, 1877-1920. Cambridge: Cambridge University Press. doi.org/10.1017/CBO9780511665080.

Wilson, JQ 1991. Bureaucracy: What Government Agencies Do and Why They Do It. New York: Basic Books.

\section{References}

American Federation of Labor and Congress of Industrial Organizations (AFL-CIO) 2001. AFL-CIO Twenty-Fourth Biennial Convention 2001: Executive Council Report. Washington, DC: AFL-CIO.

Anechiarico, F and Jacobs, JB 1996. The Pursuit of Absolute Integrity: How Corruption Control Makes Government Ineffective. Chicago: Chicago University Press. 
Bakhtin, MM 1986. Speech Genres and Other Late Essays. Austin: Texas University Press.

Berger, PL and Luckman, T 1966. The Social Construction of Reality: A Treatise in the Sociology of Knowledge. Garden City, NY: Doubleday.

Braithwaite, J 2006a. 'Accountability and responsibility through restorative justice', in MWDowdle (ed.),Public Accountability:Designs, Dilemmas and Experiences. Cambridge: Cambridge University Press, pp. 33-51.

Braithwaite, J 2006b. 'Responsive regulation and developing economies', World Development 34: 884-98. doi.org/10.1016/j. worlddev.2005.04.021.

Courville, S 2006. 'Understanding NGO-based social and environmental regulatory systems: Why we need new models of accountability', in MW Dowdle (ed.), Public Accountability: Designs, Dilemmas and Experiences. Cambridge: Cambridge University Press, pp. 271-300.

Dicey, AV 1982. Introduction to the Study of the Law of the Constitution. 10th edn, ECS Wade, ed. London: Macmillan.

Diiulio, J, jr, and Kettl, DF 1995. Fine Print: The Contract with America, Devolution and the Administrative Realities of American Federalism. CPM 95-1. Washington, DC: The Brookings Institution's Center for Public Management.

Dorf, MC 2006. 'Problem-solving courts and the judicial accountability deficit', in MW Dowdle (ed.), Public Accountability: Designs, Dilemmas and Experiences. Cambridge: Cambridge University Press, pp. 301-28.

Dowdle, MW 2006. 'Public accountability in alien terrain: Exploring for constitutional accountability in the People's Republic of China, in MW Dowdle (ed.), Public Accountability: Designs, Dilemmas and Experiences. Cambridge: Cambridge University Press, pp. 329-87.

Dunn, J 2000. The Cunning of Unreason: Making Sense of Politics. London: Basic Books.

Erkkilä, T 2007. 'Governance and accountability: A shift in conceptualisation', Public Administration Quarterly 31: 1-38. 
Foley, M 1990. Laws, Men and Machines: Modern American Government and the Appeal of Newtonian Mechanics. London: Routledge.

Gardner, J 2006. 'The mark of responsibility (with a postscript on accountability)', in MW Dowdle (ed.), Public Accountability: Designs, Dilemmas and Experiences. Cambridge: Cambridge University Press, pp. 220-42.

Habermas, J 1989. The Structural Transformation of the Public Sphere. Cambridge, Mass.: MIT Press.

Hohfeld, WN 2001. Fundamental Legal Conceptions as Applied in Judicial Reasoning. D Campbell and P Thomas, eds. Aldershot, UK: Ashgate/Dartmouth.

Hood, C 1995. 'The "new public management" in the 1980s: Variations on a theme', Accounting, Organizations and Society 20: 93-109. doi. org/10.1016/0361-3682(93)E0001-W.

Horowitz, M 1992. The Transformation of American Law, 1870-1960: The Crisis of Legal Orthodoxy. New York: Oxford University Press.

Human Rights Watch 1999. 'No Kosovo settlement without accountability for war crimes', Press release, 6 February, Human Rights Watch, New York.

Jayasuriya, K 2001. 'Governance, post Washington consensus and the new anti-politics', in T Lindsey and H Dick (eds), Corruption in Asia: Rethinking the Governance Paradigm. Sydney: The Federation Press, pp. 24-36.

JUSTICE-All Souls Review Committee 1988. Administrative Justice: Some Necessary Reforms. Oxford: Clarendon Press.

Kagan, E 2001. 'Presidential administration', Harvard Law Review 114: 2245-385. doi.org/10.2307/1342513.

Keyssar, A 2000. The Right to Vote: The Contested History of Democracy in the United States. New York: Basic Books.

Layard, R and Glaister, S (eds) 1994. Cost-Benefit Analysis. 2nd edn. Cambridge: Cambridge University Press. 
Lee, M 2011. 'History of US public administration in the progressive era: Efficient government by and for whom?', Journal of Management History 17: 88-101. doi.org/10.1108/17511341111099574.

Light, P 1999. The True Size of Government. Washington, DC: Brookings Institution Press.

Looney, R 2004. 'DARPA's policy analysis market for intelligence: Outside the box or off the wall?', International Journal of Intelligence and Counter Intelligence 17: 405-19. doi.org/10.1080/ 08850600490446745.

Loughlin, M 2010. Foundations of Public Law. Oxford: Oxford University Press. doi.org/10.1093/acprof:oso/ 9780199256853.001.0001.

Madison,J 1961. 'The Federalist no. 52', in JE Cooke (ed.), The Federalist. Middletown, Conn.: Wesleyan University Press, pp. 384-90.

Mashaw, JL 2006. 'Accountability and institutional design: Some thoughts on the grammar of governance', in MW Dowdle (ed.), Public Accountability: Designs, Dilemmas and Experiences. Cambridge: Cambridge University Press, pp. 115-56.

Mazower, M 1999. Dark Continent: Europe's Twentieth Century. New York: Alfred A. Knopf.

Morgan, B 2006. 'Technocratic v. convivial accountability', in MW Dowdle (ed.), Public Accountability:Designs, Dilemmas and Experiences. Cambridge: Cambridge University Press, pp. 243-70.

Pinker, S 2002. The Blank Slate: The Modern Denial of Human Nature. New York: Penguin Books.

Piore, MJ and Sabel, CF 1984. The Second Industrial Divide: Possibilities for Prosperity. New York: Basic Books.

Polanyi, M 1958. Personal Knowledge: Towards a Post-Critical Philosophy. Chicago: University of Chicago Press.

Rodrik, D 1999. The New Global Economy and Developing Countries: Making Openness Work. Washington, DC: Institute for International Economics. 
Rubin, E 2006. 'The myth of non-bureaucratic accountability and the anti-administrative impulse', in MW Dowdle (ed.), Public Accountability: Designs, Dilemmas and Experiences. Cambridge: Cambridge University Press, pp. 52-82.

Sabel, CF 1994. 'Learning by monitoring: The institutions of economic development', in NJ Smelser and R Swedberg (eds), Handbook of Economic Sociology. Princeton, NJ: Princeton University Press, pp. 137-65.

Savas, ES and Schubert, A 1987. Privatization: The Key to Better Government. Chatham, NJ: Chatham House.

Schneiderman, D 1977. 'AV Dicey, Lard Watson, and the law of the Canadian constitution in the late nineteenth century', Law and History Review 16: 495-526. doi.org/10.2307/744242.

Scott, C 2006. 'Spontaneous accountability', in MW Dowdle (ed.), Public Accountability: Designs, Dilemmas and Experiences. Cambridge: Cambridge University Press, pp. 174-91.

Tocqueville, A 1969. Democracy in America. JP Mayer, ed., G Lawrence, trans. Garden City, NY: Doubleday.

Weber, M 1947. The Theory of Social and Economic Organization. T Parsons, ed., AM Henderson and T Parsons, trans. New York: Free Press.

White, GE 1978. Patterns of American Legal Thought. Indianapolis: Bobbs-Merrill.

Wilson, EO 1998. Consilience: The Unity of Knowledge. New York: Alfred A. Knopf. 
This text is taken from Regulatory Theory: Foundations and applications, edited by Peter Drahos, published 2017 by ANU Press, The Australian National University, Canberra, Australia. 